\title{
EMPLOYING OPTICAL MEASUREMENTS FOR MONITORING AND DIAGNOSTICS OF COMBUSTION PROCESS IN INDUSTRIAL CONDITIONS
}

\author{
Waldemar Wójcik', Batyrbek Suleimenov², Muhtar Junisbekov ${ }^{3}$, \\ Aliya Kalizhanova ${ }^{4}$, Saule Smailova ${ }^{5}$ Rassulbek Mussabekov ${ }^{6}$ \\ 1 Electrical Engineering and Computer Science Faculty, Lublin University of Technology, Nadbystrzycka 38A, \\ 20-618 Lublin, Poland, e-mail: waldemar.wojcik@pollub.pl \\ 2 Satbayev Kazakh National Technical University, Almaty, Kazakhstan \\ 3 M.Kh. Dulaty Taraz State University, Kazakhstan \\ 4 Al-Farabi Kazakh National University, Almaty, Kazachstan \\ 5 D. Serikbayev East Kazakhstan State Technical University, Ust-Kamenogorsk, Kazakhstan \\ ${ }^{6}$ Almaty University of Power Engineering and Telecommunications, Almaty, Kazakhstan
}

Received: 2016.10.15

Accepted: 2016.11.16

Published: 2017.01.01

\begin{abstract}
The paper discusses some practical problems conected with introdction of modern coal combustion technologies as well as biomass co-combustion. In order to ensure that the combustion process runs in a proper way, the multichannel fiber optic monitoring system was applied. The system converts the optical signals coming from several flame zones to electrical that were further transmitted to the control room. The article prsents signal analyses made in time-frequency domain using short-time Fourier transform and wavelet transform and the way of their visualization to power boiler operators.
\end{abstract}

Keywords: combustion process, fiber optic probe, signal analysis.

\section{INTRODUCTION}

The growing population of Earth and civilizational development are both connected with an increase in the demand for electricity and thermal energy. To date, these have mainly been produced in thermal energy systems, due to the common usage of fossil fuels. This leads to a substantial depletion of natural resources and pollution of the atmosphere. Increasing costs of living - a major part of which includes the cost of energy - are mainly experienced by average people (Pawłowski \& Pawłowski, 2016). Ensuring adequate primal energy supply is a task which requires rationalization of energy resource management. Restoring and developing its production potential becomes a necessity. Simultaneously, a lot of attention is drawn to the mitigation of harmful impact on the natural environment. Therefore, implementation of sustainable development necessitates introducing new technologies related to the production of energy carriers, including the ones involving renewable energy sources (Czaja \& Kwaśniewski 2016).

The current energy system is a result of decisions made many years ago. Hence, it needs to be modernized, taking into consideration diversified sources of energy.

The climate objectives (known as " $3 \times 20$ "), which were adopted in 2008 by the European Parliament, show the assumptions of a new energy policy. It involves limiting the energy consumption and greenhouse gases emissions by $20 \%$, as well as increasing the share of renewable energy sources by $20 \%$ till the year 2020 . Implementation of these objectives in the domestic energy economy requires modernization and restoration of the production potential. The most important trends include:

- reducing the share of black and brown coal in the total primary fuel consumption,

- increasing the use of gas fuels (mainly natural gas), 
- increasing the share of co-generation,

- increasing the share of renewable fuels (including biomass and waste),

- decentralization of energy system through the introduction of distributed generation,

- utilizing highly efficient low-carbon technologies.

Realization of these assumptions requires huge investments. Technologies which reduce the emission of greenhouse gases and utilize renewable energy sources are characterized by high costs. This limits their applications.

The costs related with the development and use of new technologies in an energy system can be considered the cost of sustainable development which must be borne by the society.

Biomass is the basic source of primary renewable energy both in Poland and European Union. It replaces fossil fuels in thermal energy systems. Its high availability and low cost significantly influences the possibility of its application for energy generation [Saidur, 2011].

Usage of solid fuels for energy generation is the fastest developing sector of energy economy in Europe. In Poland, the availability of biomass is relatively high in relation to other renewable energy sources. It is used for energy generation through direct combustion process in various boilers. In recent years, methane fermentation in biogas plants and thermal gasification has become increasingly popular. Gasification usually denotes thermal processing of biomass, which comprises the following processes:

- drying and heating;

- pyrolysis (degasification);

In the course of pyrolysis, volatile gaseous elements are released at elevated temperatures in the absence of oxygen. The process temperature ranges from 200 to $600^{\circ} \mathrm{C}$. The products include:

- artificial artificaial solid fuel (semi-coke, coke) with negligible amount of volatiles,

- liquid products in the form of tar and gas liquor

- combustible gas, mainly comprising: $\mathrm{CO}_{2}$, $\mathrm{CO}, \mathrm{CH}_{4}, \mathrm{H}_{2}$, and $\mathrm{H}_{2} \mathrm{O}$. It also contains higher hydrocarbons which create, socalled, tarry substances.

- gasification.

Gasification of carbonized and degassed solid and liquid fraction involves numerous exothermic and endothermic chemical reactions (in oxygen deficient environment), coupled with heat and mass exchange processes. Combustible components such as $\mathrm{CO}, \mathrm{H}_{2}$ and $\mathrm{CH}_{4}$ are created as a result. The temperature in gasification process is usually higher than $750{ }^{\circ} \mathrm{C}$ [Komada et al. 2016; Komada \& Cieszczyk 2013; Wojcik et al. 2005].

Previous experiments indicate that due to the necessity of ensuring high reliability of and availability of the system, only certain types of biomass are suitable for thermal gasification. The most used ones include: firewood, waste wood produced in the course of technological processes, wastes from agricultural and lumber production, municipal waste and waste fuels (pellets), sewage and paper sludge, wood cuttings, energy crops, imported resources (e.g. nutshells, exotic tree wastes) [Mukhanov et al. 2012]. At present, wood in different forms is the most commonly used material.

Despite numerous advantages of biomass gasification systems, biomass is used most often in co-combustion in large boilers, both in commercial and industrial power industries. Relatively high efficiency of power production constitutes the advantage of direct biomass co-combustion in large energy plants.

As it was mentioned earlier, utilizing biomass as an important renewable energy source can be considered in many aspects determined by costs. The co-combustion of biomass and coal dust constitutes the simplest and least expensive process. It is assumed that the content of biomass lower than $10 \%$ - with prior pulverization in a mill enables co-combustion in a coal boiler. Certain problems arise due to its low susceptibility to pulverization. Biomass content greater than $10 \%$ requires initial pulverization and supply to burners, followed by thorough milling. Unfortunately, the $20 \%$ is a maximum value, which should not be exceeded, otherwise resulting in lower efficiency of devices and operational hazard. Employing an additional installation for processing the biomass into biogas combusted in a special burner constitutes an alternative solution. The produced heat is then used in the existing boiler.

Biomass can also be utilized in distributed generation. Important issues include highly efficient production of electricity employing fuel cells powered by gas obtained through gasification [Spallina et al. 2015] and employing biogas in combustion car engines that power generators [Hagos, Aziz, Sulaiman 2014]. The efficiency of electricity production can reach $60 \%$ with the 
use of fuel cells and $40 \%$ in the case of combustion engine. Unfortunately, raw gas obtained by means of a gasifier must be purified prior to being used in most applications. Purification is carried out to ensure uniform quality of the biogas used in other processes and involves dust and tar removal. It should be noted that the presence of tars in a gas is not always unfavourable. Tars, being hydrocarbons, are characterized by high calorific value that is advantageous for the calorific value of the gas itself. However, utilizing tars necessitates supplying them right to the destination place of gas. This means that the temperature in the entire system needs to be maintained at $400-500^{\circ} \mathrm{C}$. It can be achieved fairly easily when gas is combusted in burners. Unfortunately, in the case of other applications, it is necessary to remove tars in an additional installation.

The use of biomass in industrial plants usually comes down to supplying it in solid form into a powdered-fuel burner, with prior pulverization in a mill or in the course of gasification and combustion of raw biogas in special burners installed in a boiler. It should be noted that the energy parameters are variable, which in turn impacts the combustion process. In order to increase the efficiency of coal combustion and its co-combustion with biomass, especially in conjunction with lowcarbon combustion technologies, it is necessary to employ monitoring and diagnostics systems. This is especially vital with high variability of boiler operation and its regulation when the efficiency drops below $50 \%$.

\section{LOW-CARBON TECHNIQUES OF COAL DUST COMBUSTION AND CO-COMBUSTION WITH BIOMASS}

In industrial burners, the rate of fuel outflow is so high that turbulent flow appears already at its outlet. Momentary values of flow parameters are not constant, but rather revolve around the mean values. These changes are caused by periodically occurring vortices of different sizes that move in a chaotic manner. Increase in the intensity of mixing is the most important feature of turbulent flow. In a turbulent flame, the gradients of all scalar values are raised, along with the intensity of molecular transport. In a turbulent vortex flame, there is no simple model which would enable its analysis.

Therefore, determining the experimental parameters of coal, as well as - in the case of co- combustion - biomass combustion process, becomes an urgent matter. No theory can be applied in practice without these parameters, because a correctly conducted combustion process, carried out by means of a burner and combustion chamber, is an economical and ecological condition of utilizing coal and biomass in utility boilers.

From the ecological point of view, so-called low-carbon combustion technology constitutes an important improvement for conducting the combustion process.

\section{Low-carbon combustion technology}

The main pollutants produced in the course of combustion process include:

- carbon dioxide $\left(\mathrm{CO}_{2}\right)$,

- sulphur dioxide $\left(\mathrm{SO}_{2}\right)$,

- nitrogen oxides $\left(\mathrm{NO}_{\mathrm{X}}\right)$.

Limiting the emission of carbon dioxide produced in combustion process is a very difficult task, because all fossil fuels contain carbon. It can be assumed that substituting part of carbon with biomass would lower the emission, as it is generally understood that combustion of biomass is characterized by zero $\mathrm{CO}_{2}$ emission (although, taking into account the energy used for its preparation for combustion, this statement is not entirely true). However, the most efficient method for mitigating $\mathrm{CO}_{2}$ emission involves rationalization of energy consumption, e.g. by employing energy-saving technologies and improving the efficiency of electricity and thermal energy production by means of the combustion process.

Sulphur oxides constitute a significant share of the atmospheric air pollution, causing acid rains what have a negative impact on the environment. Moreover, their corrosive nature contributes to accelerated wear of boilers and turbines. Lowering $\mathrm{SO}_{2}$ emission is conducted in special desulphurization plants. As its residence time in the atmosphere ranges from 24 hours to 4 days, it can be moved over a considerable distance.

Nitrogen creates nitrogen oxides, from $\mathrm{NO}$ to $\mathrm{N}_{2} \mathrm{O}_{5}$, but only three of them, i.e. $\mathrm{N}_{2} \mathrm{O}$, NO and $\mathrm{NO}_{2}$, can be created through combustion. Their properties differ, for instance $\mathrm{N}_{2} \mathrm{O}$ is not poisonous and is used in medicine as an anaesthetic. The process of combustion yields the greatest amounts of $\mathrm{NO}$ and small amounts of $\mathrm{NO}_{2}$. The notion of $\mathrm{NO}_{\mathrm{X}}$, which corresponds to a mixture of $\mathrm{NO}$ and $\mathrm{NO}_{2}$ (sum of $\mathrm{NO}+\mathrm{NO}_{2}$ per $\mathrm{NO}_{2}$ ), is employed in combustion technology. Nitrogen 
oxides $\mathrm{NO}_{\mathrm{X}}$ contribute to the local air pollution to the greatest degree, leading to creation of acid rains, photochemical smog, and the ozone hole. Mitigation of NOx emission in the combustion process can be realized:

- inside the boiler,

- outside the boiler.

The first group includes:

- low-carbon combustion technology, so-called primary methods

- methods involving introduction of additional reducing agents, e.g. ammonia or urea,

In the second group, $\mathrm{NO}_{\mathrm{x}}$ is removed from the exhaust gases by means of catalytic reductions:

- selective (SCR),

- non-selective,

as well as absorption methods.

Employing primary methods, despite having the lowest efficiency of $\mathrm{NO}_{\mathrm{x}}$ emission removal, became the most common solution owing to their low cost.

Low-carbon combustion technology involves organizing the process in the way that ensures reduced $\mathrm{NO}_{\mathrm{x}}$ emission in comparison to the conventional combustion system.

This can be carried out by:

- lowering the combustion temperature,

- changing the air distribution,

- changing the combusiton aerodynamics,

- utilizing the reducing properties of so-called rich flame.

In the case of coal dust combustion, especially in co-combustion with biomass, lowering the temperature is limited by the possibility of losing the process stability. This is particularly important when a boiler operates at efficiency lower than $50 \%$. Low-carbon combustion with gradable air supply involves creation of two zones in the combustion chamber:

- $\operatorname{rich}(\lambda<1)$,

- $\operatorname{poor}(\lambda>1)$,

where $\lambda$ stands for the stoichiometric coefficient.

In the first zone, combustion occurs in oxygen deficient environment. Thus, a reducing zone with lowered temperature is created. Afterburning with controlled oxygen excess takes place in the second zone. This method has the greatest impact on the scale of $\mathrm{NO}_{\mathrm{X}}$ emission reduction in the rich combustion zone. During the thermal decomposition of fuel, the fuel-nitrogen $\mathrm{CN}$ transforms into volatile products of its de- composition, i.e. simpler nitrogen compounds. Flammable hydrogen cyanide (HCN) and ammonia $\left(\mathrm{NH}_{3}\right)$, which may be oxidized to $\mathrm{NO}_{\mathrm{X}}$ in the presence of oxygen, are most common. In the rich zone, due to oxygen deficiency, the bulk of $\mathrm{HCN}$ and $\mathrm{NH}_{3}$ is converted to $\mathrm{N}_{2}$, as well as nitrogen and amine radicals $\left(\mathrm{N}, \mathrm{NH}, \mathrm{NH}_{2}\right)$, which are capable of reducing $\mathrm{NO}_{\mathrm{X}}$. Attention should also be drawn to the role of hydrocarbon radicals $\mathrm{CH}$, found in significant concentration in the combustion zone. They are characterized by a great $\mathrm{NO}_{\mathrm{X}}$ reduction capacity, but unfortunately, this reaction also yields $\mathrm{HCN}$.

In the second zone (where afterburning occurs) a small excess of oxygen is found. This results in the oxidation of $\mathrm{HCN}$ and $\mathrm{NH}_{3}$ from the first zone into $\mathrm{NO}_{\mathrm{x}}$. The efficiency of $\mathrm{NO}_{\mathrm{x}}$ mitigation carried out with air gradation method is influenced by the conditions in the first rich zone. These mainly include:

- residence time, which should not be shorter than $1 \mathrm{~s}$ (primarily depending on the boiler output),

- air excess coefficient $\lambda$, which should approximate $0.7-0.8$ (air excess greater than 0.8 raises $\mathrm{NO}_{\mathrm{x}}$ generation in the first zone, while lower than 0.7 increases the $\mathrm{HCN}$ and $\mathrm{NH}_{3}$ share in the first zone, which are subsequently oxidized to $\mathrm{NO}_{\mathrm{x}}$ in the second one).

Employing low-carbon combustion technologies, especially in the case of coal dust co-combustion with biomass which is often insufficiently pulverized, results in the occurrence of side-effects involving:

- low-oxygen corrosion,

- increase of combustible elements in ash and slag,

- greater CO share in exhaust gases,

- greater fouling

- accelerated erosion of burner system,

- deterioration of combustion stability.

In spite of these disadvantages, the low-carbon combustion technology is widely-employed, while the current directions of research strive for the minimization of its costs. This objective is realized through the use monitoring or monitoring and diagnostics systems - which evaluate the operation of individual burners - as well as the systems controlling the information found in the flame [Smolarz, Lytvynenko, Koshukova 2013; Smolarz, Wójcik, Gromaszek 2012; Sawicki et al. 2016; Mashkov, Smolarz Lytvynenko 2016; Wojcik, Golec, Kotyra, Komada 2004]. 


\section{THE SYSTEM FOR MONITORING AND DIAGNOSTICS OF COMBUSTION PROCESS IN INDUSTRIAL CONDITIONS}

The combustion process is determined by a number of factors. The most important ones include:

- the nature of fuel and air mixture flow through the reaction zone, which has a significant influence on the exchange processes of mass, heat, and momentum;

- the mixing degree of oxidizing agent and fuel at the reaction zone inlet.

In industrial conditions, the fuel and oxidizing agent are usually not thoroughly mixed in the burner. They are usually supplied in the form of so-called primary air (fuel, usually coal dust or a mixture of coal dust and biomass, mixed with a small amount of air enabling transportation in dust pipes and the burner itself) and so-called secondary air (the air necessary for combustion). In technical conditions, the amount of primary and secondary air is insufficient for total combustion; therefore, additional air is supplied through OFA and SOFA nozzles. They provide a small excess of air in the afterburning zone $(\lambda>1)$, enabling total combustion, which yields $\mathrm{CO}_{2}$. Unfortunately, total combustion is not achieved in this process, and the underburnt remains may reach up to $5 \%$.

In the case of coal dust combustion or its cocombustion with biomass in industrial combustions, the flow at the burner outlet is turbulent. Controlling the combustion process in such conditions is extremely difficult [Bayas et al. 2016]. Additionally, attention should be drawn to the fact that at present, there is no direct measurement of the primary air supplied to the burner. This amount is estimated in a collective dust pipe on the basis of the mill fan load. As multiple burners are supplied from one dust pipe, the primary air is distributed in an uneven manner. This in turn impacts the efficiency of the combustion process [Pronobis, 2006]. Due to the common pipe, measurement of parameters at the outlet of the combustion chamber yields not only belated, but also averaged results, with no possibility of detecting incorrect operation of a single burner [Smolarz et al. 2012, Mashkov et al. 2014]. Hence, effort should be made to equip each burner with separate monitoring and diagnostics systems, which would constitute an important step towards improving the process efficiency [Sami et al. 2010; Gozhyi et al. 2012; Kotyra 2014].
The solutions that utilize the following technologies can be employed [Docquier \& Candel 2002]:

a) fibre-scopes and $\mathrm{CCD} / \mathrm{CMOS}$ cameras, which enable monitoring the selected combustion zone on a screen [Kotyra et al. 2014, Jiang, Luo, Zhou, 2009, Sawicki, Kotyra 2014],

b) analysis of free radicals in a specified flame zone [Smolarz, Ballester, Garcia-Armingol 2013, Cięszczyk 2013],

c) fibre-optic systems which enable evaluation of burner operation in the combustion process on the basis of changes in the illumination intensity of flame in a selected zone, both in the amplitude and frequency [Kotyra et al. 2013], d) spectral analysis of the combustion process [Cięszczyk et al. 2016].

A monitoring and diagnostics system should also be applicable for the boiler lighting-up, which consists of the following phases:

- switching on of the gas lighting-up burner,

- switching on of the mazut burner,

- switching on of the dust burner,

Therefore, the solution no. 3, which seems most flexible, was chosen. The system comprises a multi-channel fibre-optic probe placed directly in the combustion chamber and an optoelectronic block which enables conducting a preliminary analysis of measurement data.

The spectral characteristics of radiation pertaining to various fuels differ significantly from one another. Therefore, a detector which would enable monitoring of each of them was required. Taking into account that the probe is placed inside the combustion chamber, where the temperature reaches $450-500^{\circ} \mathrm{C}$, a high temperature-resistant fibre-optic that enables continuous operation at $700^{\circ} \mathrm{C}$ was used [Dziubiński et al. 2016]. Such placement of the probe exposes it to hot solids. Hence, an additional quartz cover was used for the protection of the fibre-optic (better results could have been achieved with sapphire cover; unfortunately, it was much more expensive). Moreover, it was assumed that the probe would operate without maintenance for at least a month. The employed special cleaning air was characterized by much lower temperature than the one inside the boiler, which resulted in slagging that necessitates a relatively frequent cleaning of the measurement probe (every several days).

In order to determine the number of channels in the probe, it was necessary to select the zones which were most sensitive to changes in the input 
signals. On the other hand, optimizing the design was required to ensure maintenance-free operation.

By employing the finite element method, the measurement probe was optimized, while the preliminary studies enabled to determine the area of monitoring zone nad the number of the zones used in diagnostics process. An optimized fibre-optic probe with optoelectronic block was presented in Figure 1, while the placement of fibre-optic probes in boilers equipped with: a) wall mounted burners, b) tangentially fired boilers are depicted in Figure 2 [Wojcik et al. 2004; Wojcik, Golec, Kotyra, Cieszczyk, Duk, Komada 2004].

\section{MEASUREMENT RESULTS}

The analysis of flame signal - proportional to the changes of its temperature -measured by means of a monitoring-diagnostics system, led to the determination of its range and rate of its variability. Exemplary results of these studies were presented in Figures $3 \div 6$.

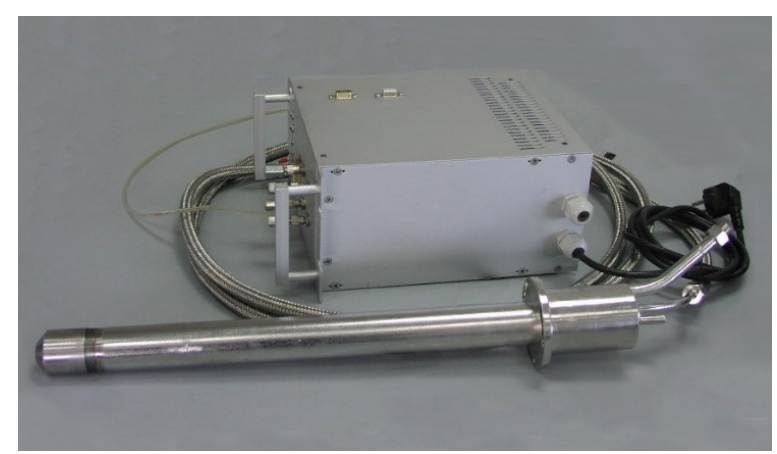

Figure 1. Fibre-optic probe with the optoelectronic block

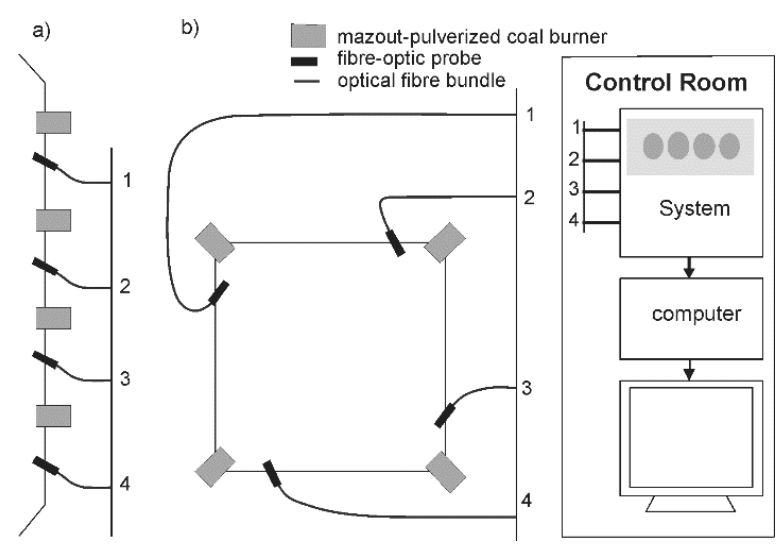

Figure 2. Placement of the fibre-optic probes in:

a) boilers with wall mounted burners, b) tangentially fired boiler
The time series are difficult to interpret; therefore, they were analyzed with continuous wavelet and Fourier transforms [Wojcik et al. 2001]. The results of wavelet analysis are presented in Figures 8-11, whereas the results of Fourier analysis are depicted in Figure 12.

As can be seen, the physical analysis of signal variability is difficult; thus, practical application in the form of a bar chart with limits of parameters marked is proposed as a solution. Examples were presented in Figure 14. On the other hand, Figure 15 shows the impact of the fuel type on the monitoring-diagnostics signal.

The analysis of the presented signals indicates that the output of monitoring-diagnostics system is sensitive to changes in parameters.

\section{CONCLUSIONS}

The conducted review and experiment results enable to formulate the following conclusions:

1. Optimized, fibre-optic monitoring-diagnostics system for the combustion process may operate in industrial conditions without maintenance for at least a month (the trials carried out in the industrial plant allowed for a successful three months of maintenance-free operation);

2 . The obtained signals enabled to conduct more advanced analyses (Fourier and continuous wavelet transforms) which allowed to determine the impact of process factors on their variability with greater accuracy;

3. Employing a monitoring-diagnostics system ensures smooth operation of burners through uniform distribution of fuel (analogous points of operation and their stabilization);

4. Ensuring stable and smooth operation of burners leads to greater efficiency of the combustion process in industrial boilers, which is especially important in the case of coal dust and biomass co-combustion;

5. Fibre-optic monitoring-diagnostics system can also be used during firing-up of the boiler, as it distinguishes between both the gas and mazut flames, thus shortening the start-up phase;

6. The signals from fibre-optic monitoring-diagnostics system are characterized by a minimal lag (lasting approximately for several dozen $\mathrm{ms}$ ) in comparison with the process parameters variability signals (up to several minutes) and can be used in combustion process regulation systems. 


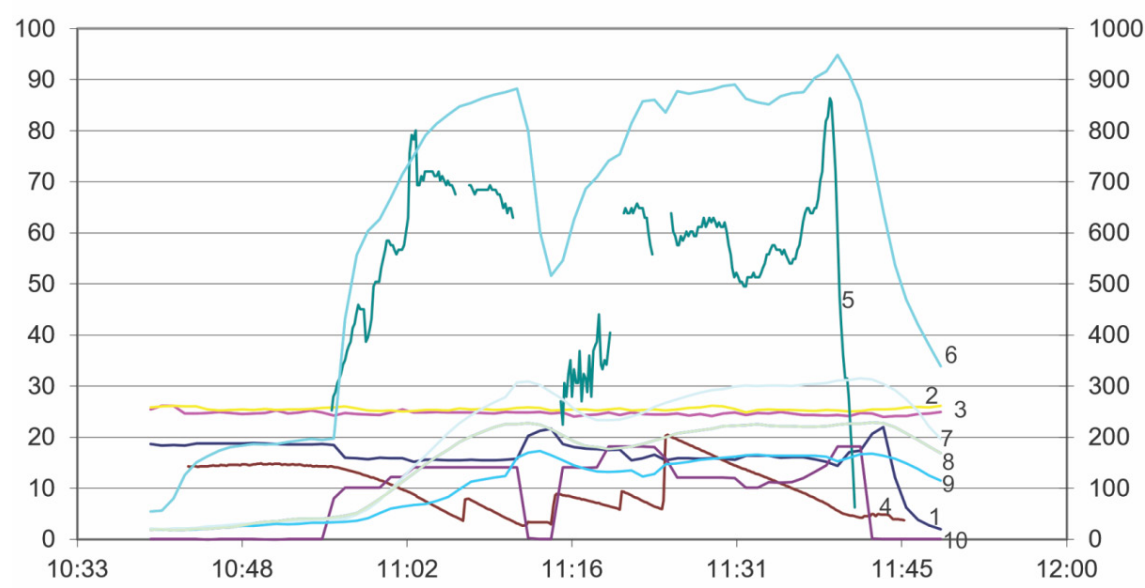

Figure 3. Changes of the selected settings of laboratory combustion facility during the selected test: 1 - rotations of the primary air fan (rpm); 2 - rotations of the secondary air fan \#1(rpm); 3 - rotations of the secondary air fan \#2(rpm); 4 - the balance redouts $(\mathrm{kg}) ; 5$ - fuel flowrate $(\mathrm{kg} / \mathrm{min}) ; 6$ - temperature inside the combustion chamber $\left({ }^{\circ} \mathrm{C}\right), 7,8,9$ - flue gas temperatures at different points of the exhaust manifold system $\left({ }^{\circ} \mathrm{C}\right), 10$ - rotations of the fuel screw conveyor (rpm).

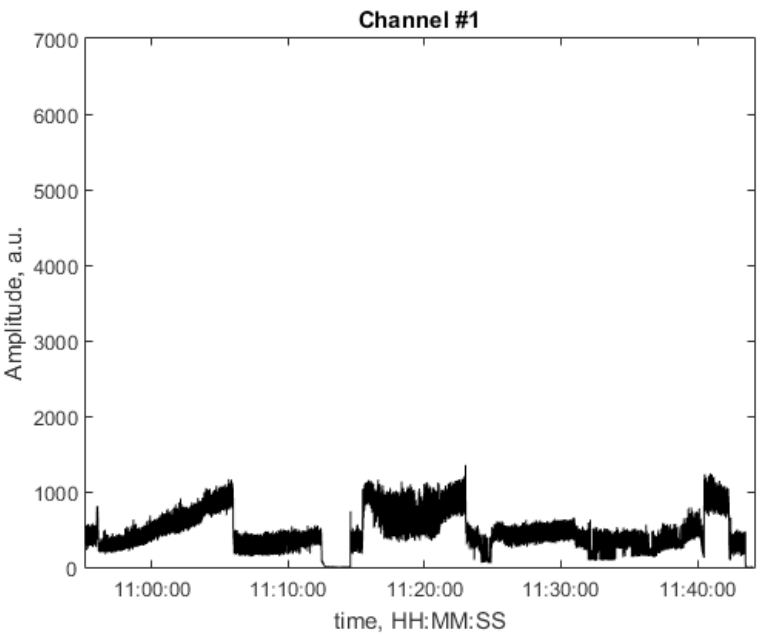

Figure 4. An examplary signal obtained from flame monitoring-diagnostics system - channel 1

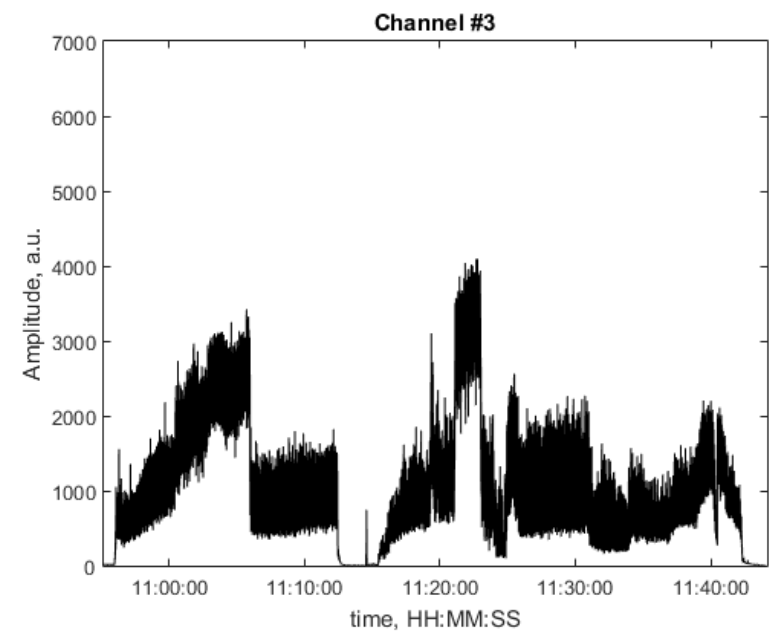

Figure 6. An example signal obtained from flame monitoring-diagnostics system - channel 3

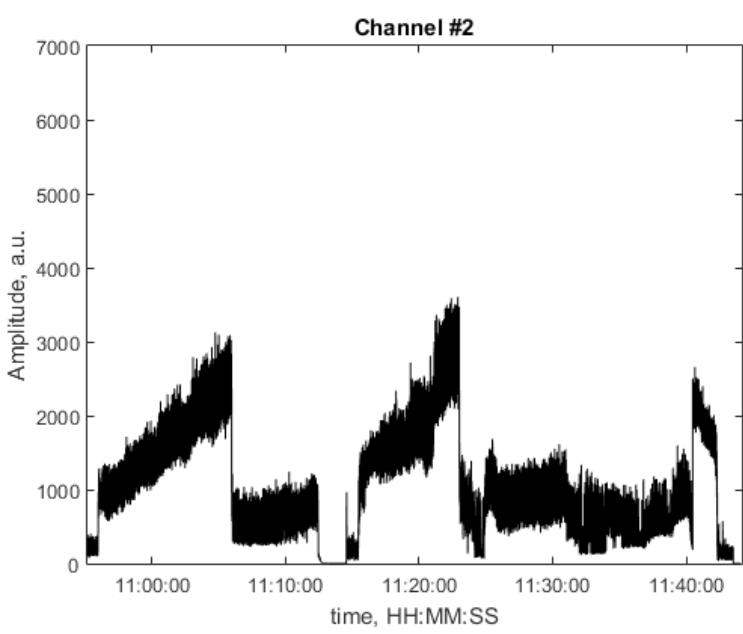

Figure 5. An example signal obtained from flame monitoring-diagnostics system - channel 2

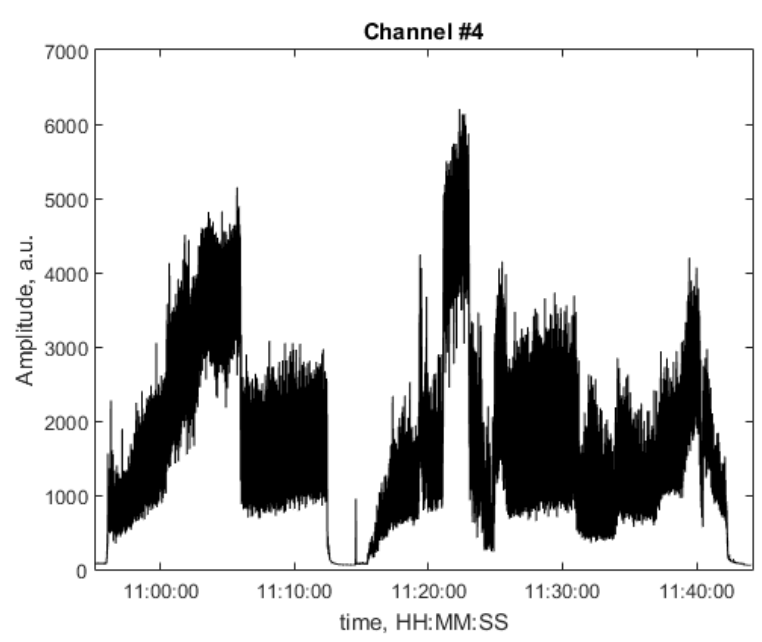

Figure 7. An example signal obtained from flame monitoring-diagnostics system - channel 4 
a)

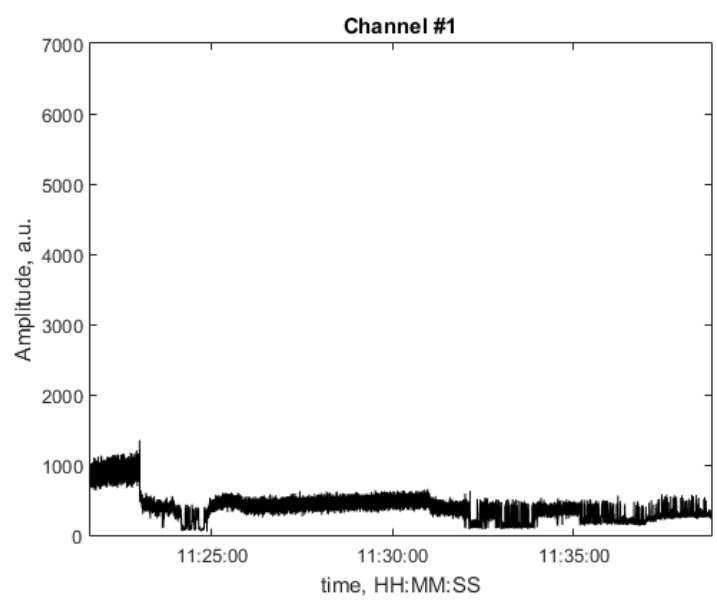

c)

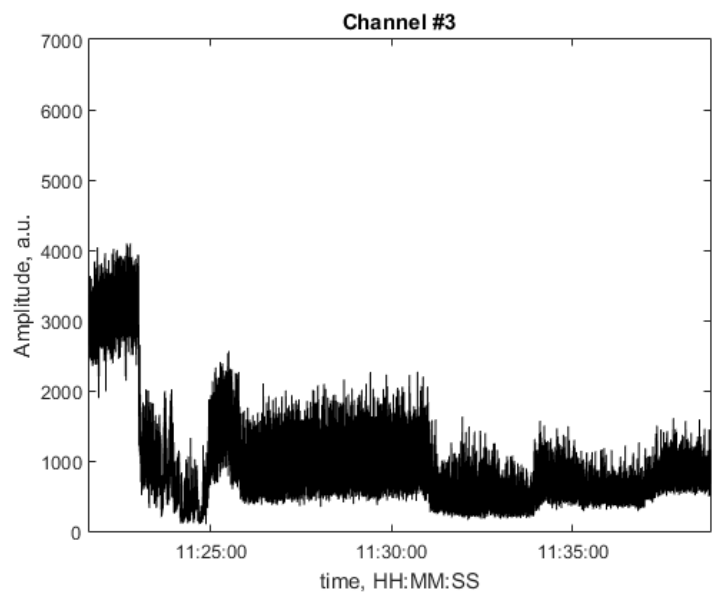

b)

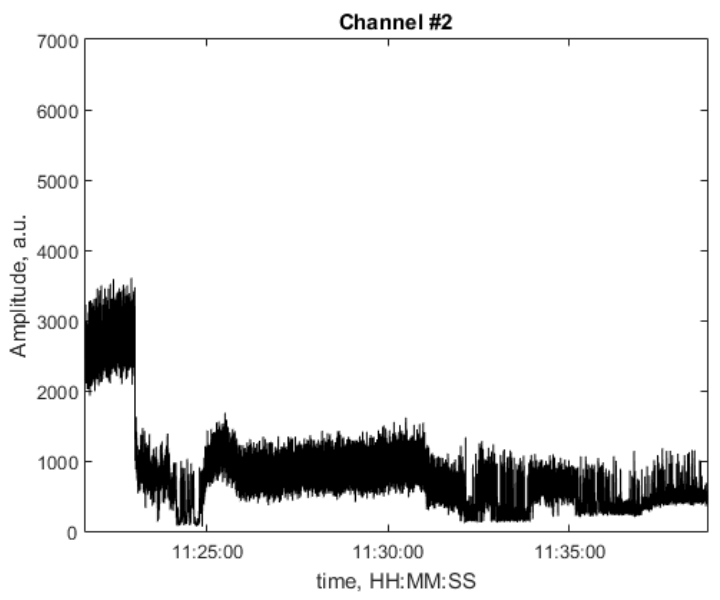

d)

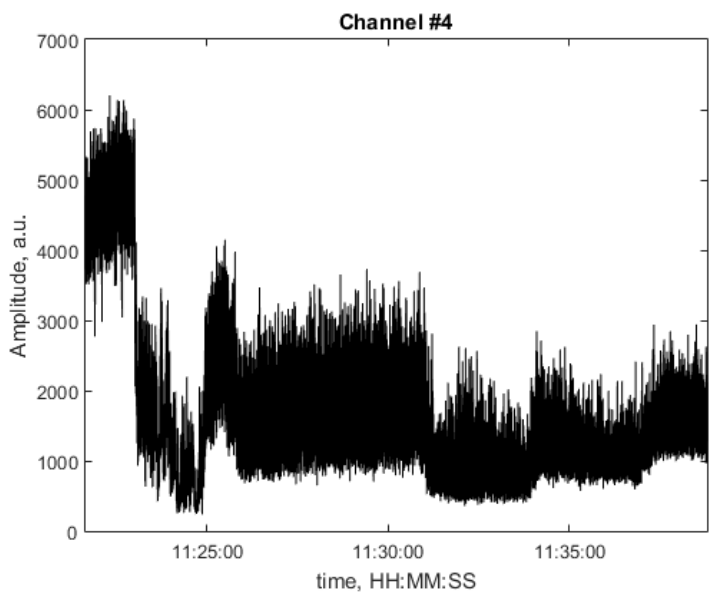

Figure 8. Signals obtained from flame monitoring-diagnostics system for further analysis: a) channel 1, b) channel 2, c) channel 3 ,d) channel 4

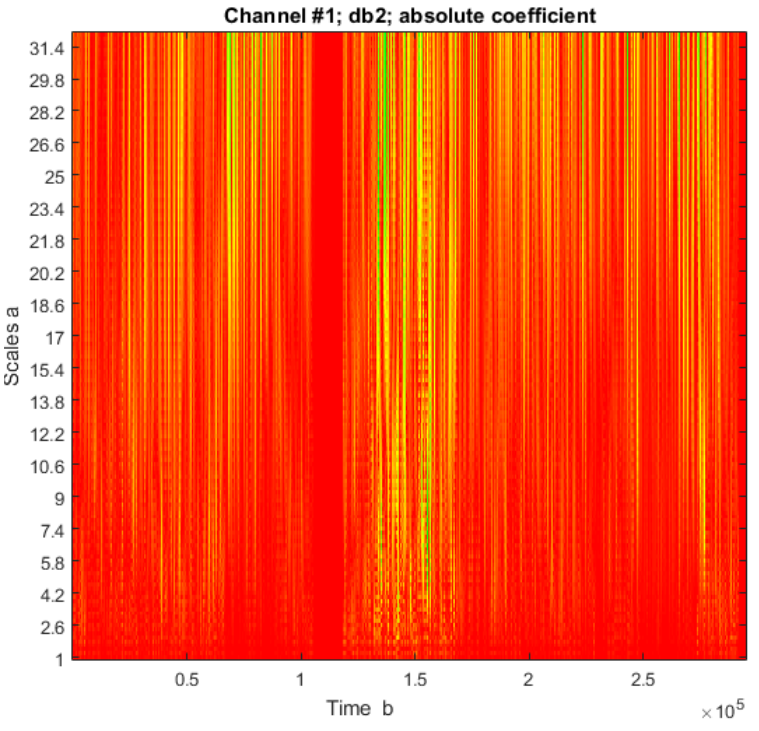

Figure 9. Scalogram obtained for continuous wavelet transform of signal that was acquired from the flame monitoring-diagnostics system - Daubechies 2 wavelet, channel 1

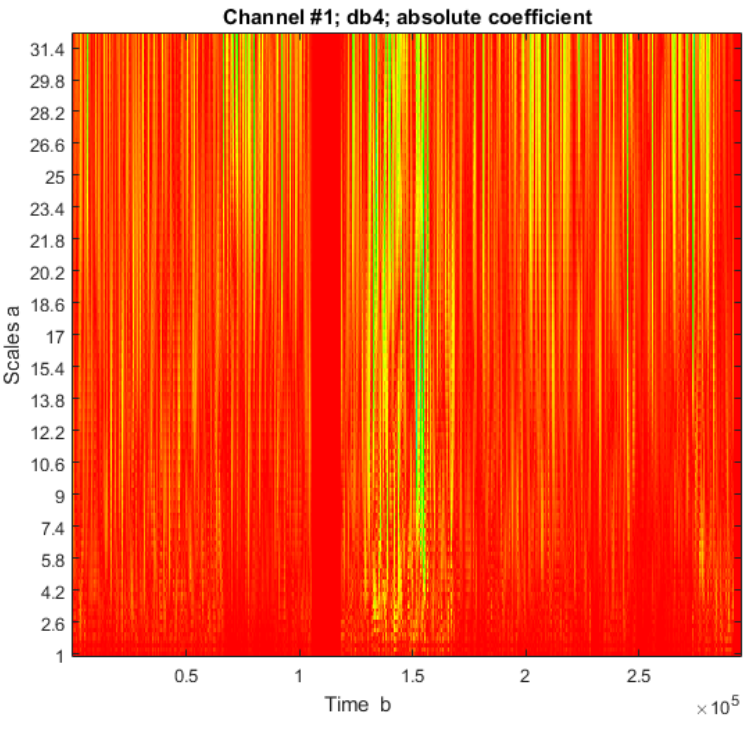

Figure 10. Scalogram obtained for continuous wavelet transform of signal that was acquired from the flame monitoring-diagnostics system - Daubechies 4 wavelet, channel 1 


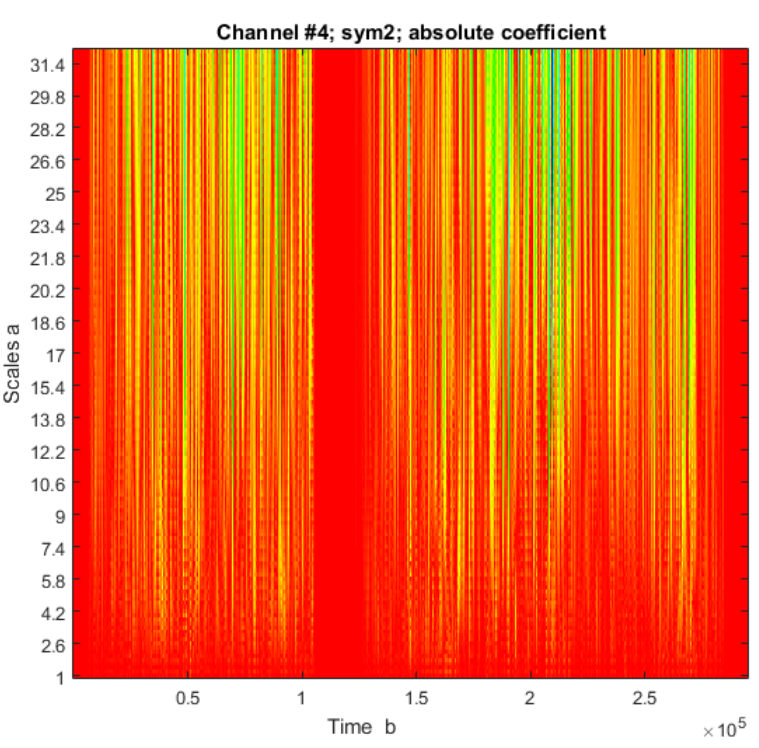

Figure 11. Scalogram obtained for continuous wavelet transform of signal that was acquired from the flame monitoring-diagnostics system - Symlet 2 wavelet, channel 4

a)

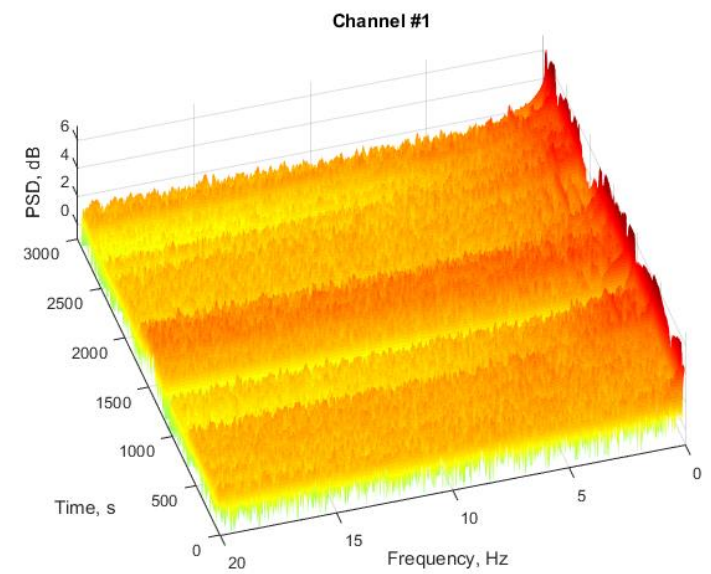

c)

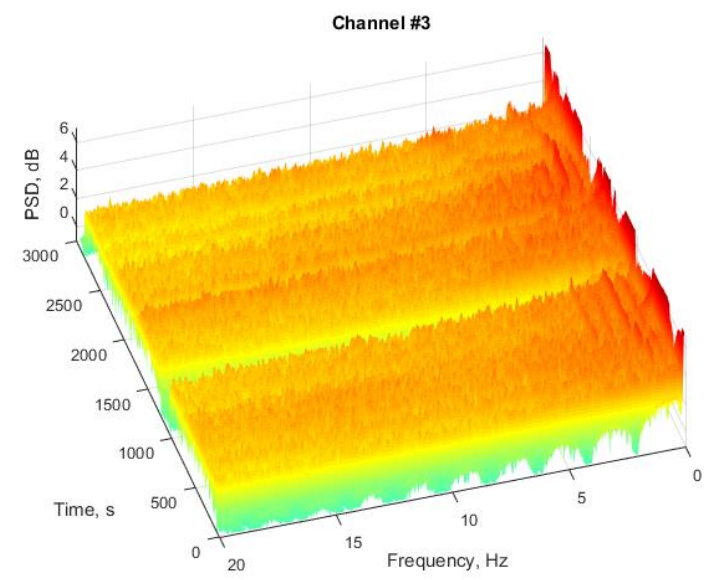

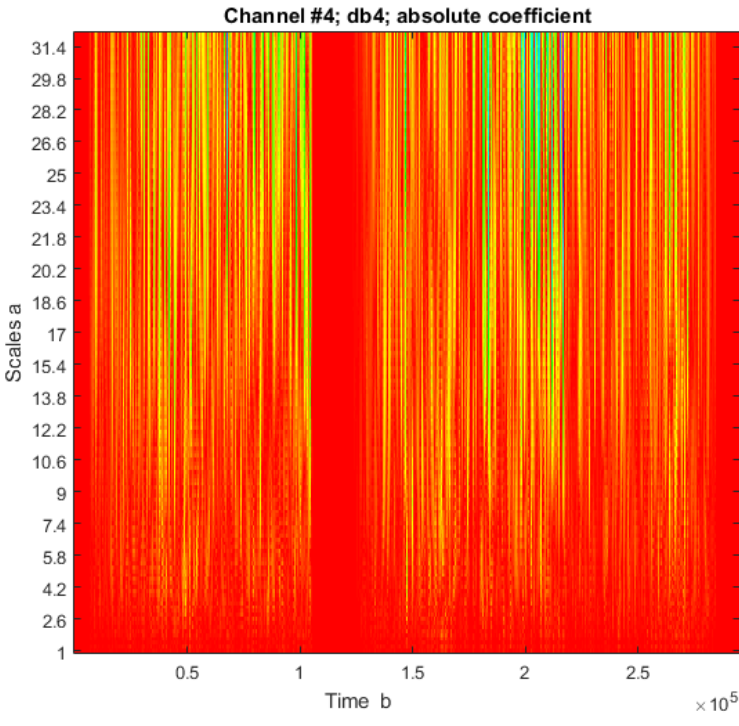

Figure 12. Scalogram obtained for continuous wavelet transform of signal that was acquired from the flame monitoring-diagnostics system - Daubechies 4 wavelet, channel 4

b)

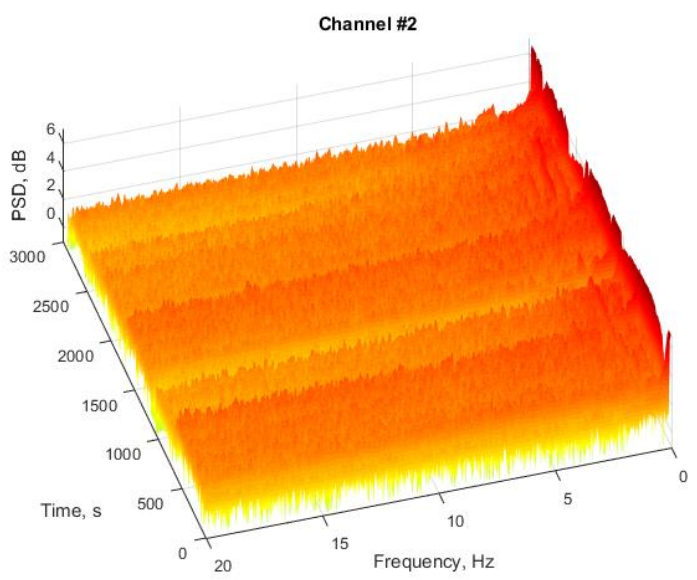

d)

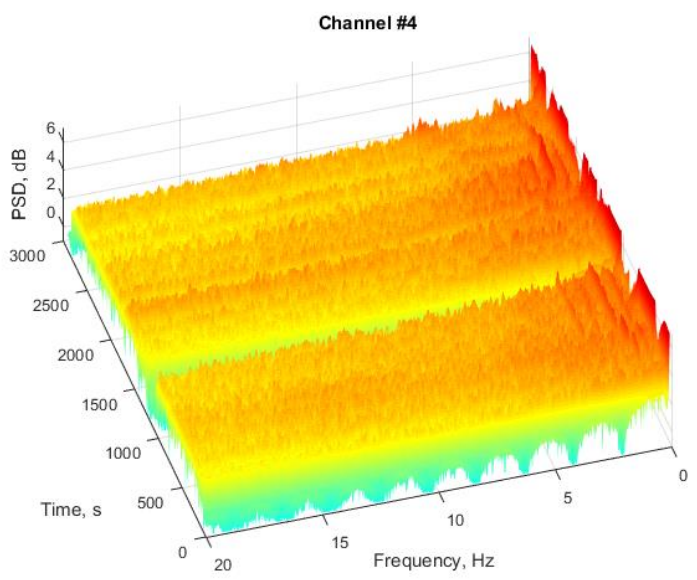

Figure 13. Short-time Fourier transform spectrograms for the selected signals (fig. 8) obtained when Blackmann window was applied (2000 samples) with sampling frequency of $100 \mathrm{~Hz}$ :

a) channel 1, b) channel 2, c) channel 3,d) channel 4 


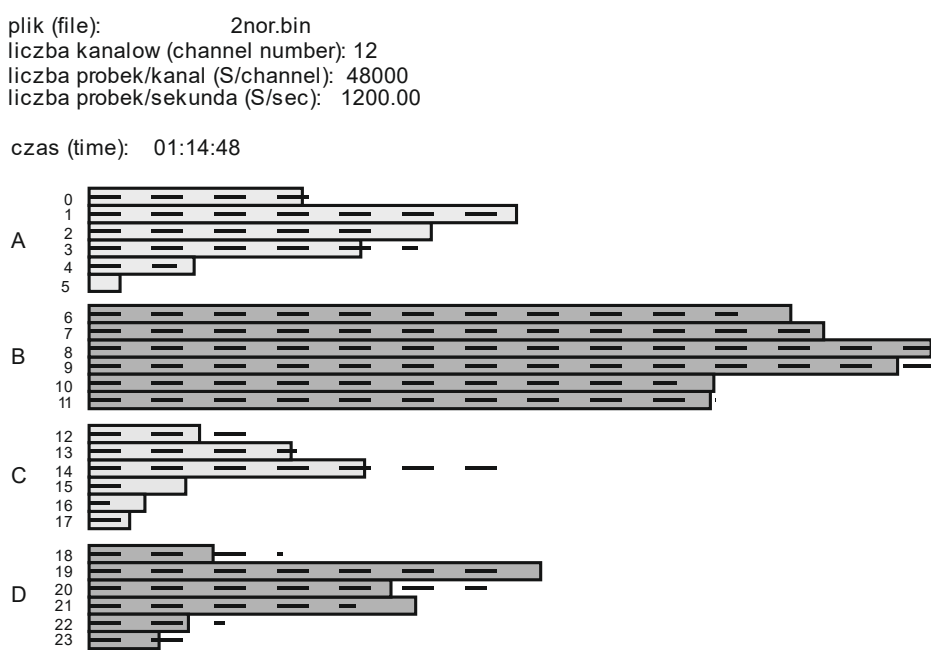

Figure 14. Combustion proces visualisation for different flame zones: $\mathrm{A}$ - signal level, $\mathrm{B}$ - the signal variable component, $\mathrm{C}$ - number of the signal variable component transitions through its average value, $\mathrm{D}$ - number of changing the sign of the signal derivative

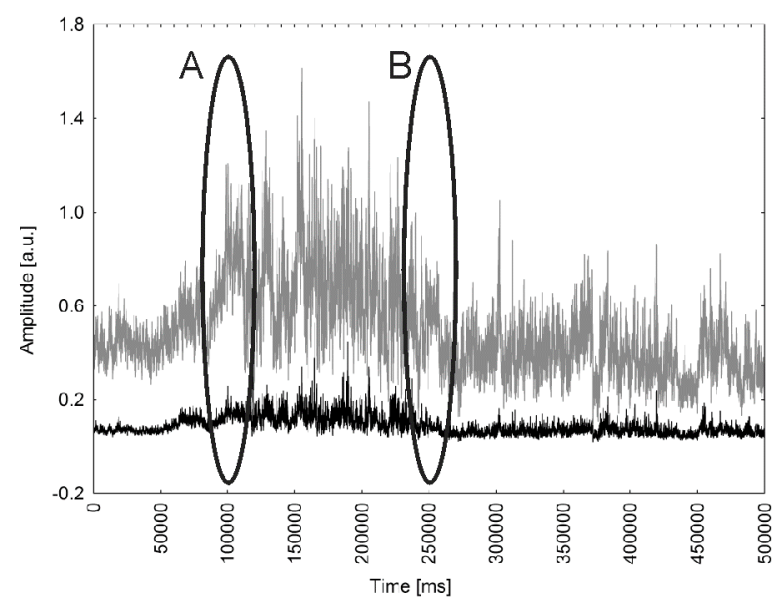

Figure 15. Signals obtained from the combustion monitoring-diagnosis system when mazut burner is switched on (A) and switched off (B).

\section{REFERENCES}

1. Bayas, M. Dubovoy, B. Shegebaeva J. Gromaszek, K. 2015. Optimization of hierarchical management of technological processes. Proceedings of SPIE 9816.

2. Cięszczyk, S. 2013. A multi-band integrated virtual calibration - inversion method for open path FTIR spectrometry. Metrology and Measurement Systems 20(2), 287-298

3. Cięszczyk, S. Komada, P. Akhmetova, A. Mussabekova, A. 2016. Metody analizy widm mierzonych z wykorzystaniem spektrometrów OP-FTIR w monitorowaniu powietrza atmosferycznego oraz gazów w procesach przemysłowych. Annual Set The Environmental Protection 18(p.2), 218-234.

4. Czaja, P. \& Kwaśniewski, K. 2016. Polski węgiel, energia i środowisko - szanse i zagrożenia. Annual
Set The Environmental Protection 18(p.2), 38-60.

5. Docquier, N. \& Candel, S. 2002. Combustion control and sensors: a review. Progress in Energy and Combustion Science 28, 107-150.

6. Dziubiński, G. Harasim, D. Skorupski, K. Mussabekov, K. Kalizhanova, A. Toigozhinova, A. 2016. Optymalizacja parametrów światłowodowych czujników do pomiaru temperatury. Annual Set The Environmental Protection 18(p.2), 309-324.

7. Geche, F. Kotsovsky, V. Batyuk, A. Mitsa, A. Gromaszek, K. 2013. Bithreshold neurons learning. Elektronika: Konstrukcje, Technologie, Zastosowania 8(54), 70-72.

8. Gozhyi, A. Burlachenko, I.Gromaszek, K. 2012. Using multiobjective genetic algorithms for optimal resource management in an autonomous power system. IAPGOŚ 4b, 48-50. 
9. Hagos, F.Y. Aziz, A.R.A. Sulaiman, A. 2014. Syngas $(\mathrm{H} 2 / \mathrm{CO})$ in a spark-ignition direct-injection engine. Part 1: Combustion, performance and emissions comparison with CNG. International Journal of Hydrogen Energy 39, 17884-17895

10. Jiang, Z. Luo, Z. Zhou, H. 2009. A simple measurement metod of temperature and emissivity of coalfired flames from visible radiation image and its application In CFB boiler furmance. Fuel 88, 980-987.

11. Komada, P. Cięszczyk, S. Zhirnova, O. Askarova, N. 2016. Optyczna metoda diagnostyki gazu syntezowego z biomasy. Annual Set The Environmental Protection 18(p.2), 271-283.

12. Komada, P. Cieszczyk, S. 2013. Application of Multiple Line Integrated Spectroscopy on CO Concentration Measurement, Elektronika Ir Elektrotechnika. 19, 46-49.

13. Kotyra, A. 2014. Optoelektroniczne systemy w zastosowaniach diagnostycznych i pomiarowych, IAPGOŚ 2, 9-10.

14. Kotyra, A. Bazil, G. Wójcik, W. Iskakova, A. 2014. Biomass co-combustion characterization based on analysis of image sequence. Przegląd Elektrotechniczny 3(90), 223-226.

15. Kotyra, A. Wójcik, W. Gromaszek, K. Popiel, P. Ławicki, T. Jagiełło, K. 2013. Detection of biomass-coal unstable combustion using frequency analysis of image series. Przegląd Elektrotechniczny 3b(89): 279-281.

16. Kotyra, A. Wójcik, W. Gromaszek, K. Smolarz, A. Jagiełło, K. 2012. Assessment of biomass-coal cocombustion on the basis of flame image. Przegląd Elektrotechniczny 11b(88): 295-297.

17. Mashkov, V. Smolarz, A. Lytvynenko, V. 2016. Development issues in algorithms for system level self-diagnosis. IAPGOŚ 1, 26-28.

18. Mashkov, V. Smolarz, A. Lytvynenko, V. Gromaszek, K. 2014. The problem of system faulttolerance. IAPGOŚ 4, 41-44.

19. Mukhanov, B. Suleimanov, A. Komada, P. 2012. Control system elaboration for phosphorite charge pelletizing process. IAPGOŚ 3, 25-27.

20. Pawłowski, A. \& Pawłowski, L. 2016. Wpływ sposobów pozyskiwania energii na realizację paradygmatów zrównoważonego rozwoju. Annual Set The Environmental Protection 18(p.2), 19-37.

21. Pronobis, M. 2006. The influence of biomass cocombustion on boiler fouling and efficiency. Fuel $85,474-480$.

22. Saidur, R. Abdelaziz, E.A. Demirbas, A. Hossain, M.S. Mekhilef, S. 2011. A review on biomass as a fuel for boilers. Renewable and Sustainable Energy Reviews 15, 2262-2289.

23. Sami, M., Annamalai, K., Wooldridge, M. 2010: Co-firing of coal and biomass fuel blends. Progress in Energy and Combustion Science 27, 171-214.

24. Sawicki, D. Kotyra, A. 2014. Monitoring combustion process using image classification, Przegląd
Elektrotechniczny 11(90), 130-132.

25. Sawicki, D. Kotyra, A. 2013. Porównanie wybranych metod wyznaczania obszaru płomienia w wizyjnym systemie diagnostycznym. IAPGOŚ 4, 14-17.

26. Sawicki, D. Kotyra, A. Imanbek, B. Suleymanov, A. 2016. Wykorzystanie metod optycznych do klasyfikacji stanu procesu współspalania pyłu węglowego i biomasy. Annual Set The Environmental Protection 18(p.2), 404-415.

27. Smolarz, A. Ballester, J. Garcia-Armingol, T. 2013. Chemiluminescence - based sensing of flame stoichiometry: Influence of the measurement method. Measurement 46(9), 3084-3097.

28. Smolarz, A. Kotyra, A. Wójcik, W. Ballester, J. 2012. Advanced diagnostics of industrial pulverized coal burner using optical methods and artificial intelligence. Experimental Thermal and Fluid Science 43, 82-89.

29. Smolarz, A. Lytvynenko, V. Koshukova, O. 2013. Combined clonal negative selection algorithm for diagnostics of combustion in individual PC burner. IAPGOŚ 4, 69-73.

30. Smolarz, A. Wójcik, W. Gromaszek, K. 2012. Fuzzy modeling for optical sensor for diagnostics of pulverized coal burner. Procedia Engineering 47, 1029-1032.

31. Spallina, V. Mastropasqua, L. Iora, P. Romano, M.C. Campanari, S. 2015. Assessment of finite volume modeling approaches for intermediate temperature Solid Oxide Fuel Cells working with $\mathrm{CO}$-rich syngas fuels. International Journal of Hydrogen Energy 40, 15012- 15031.

32. Wojcik, W. Golec, T. Kotyra, A. Smolarz, A. Komada, P., Kalita, M. 2004. Concept of application of signals from fiber-optic system for flame monitoring to control separate pulverized coal burner. Photonics Applications in Astronomy, Communications, Industry, and High-Energy Physics Experiments. Proceedings of SPIE 5484, 427-431.

33. Wojcik, W. Golec, T. Kotyra, A. Cieszczyk, S. Duk, M. Komada, P. 2004. Application of flame monitoring system for flame spectrum analysis in industrial conditions. Lightguides and Their Applications. Proceedings of SPIE 5576, 377-380.

34. Wojcik, W. Golec, T. Kotyra, A. Komada, P., 2004. Optoelectronic controller for pulverized coal burner. Modern Problems of Radio Engineering, Telecommunications and Computer Science. Proceedings of SPIE, 507-509.

35. Wojcik, W. Komada, P. Cieszczyk, S. Firago V. 2005. ECTL application for carbon monoxide measurements, Lasers and Applications. Proceedings of SPIE 5958, 102-119.

36. Wojcik, W. Kotyra, A. Smolarz, A. Komada, P. Wojciechowski, C. 2001. Application of wavelet transform in detection of flame instabilities. Optoelectronic and Elctronic Sensors. Proceedings of SPIE 4516, 277-280. 